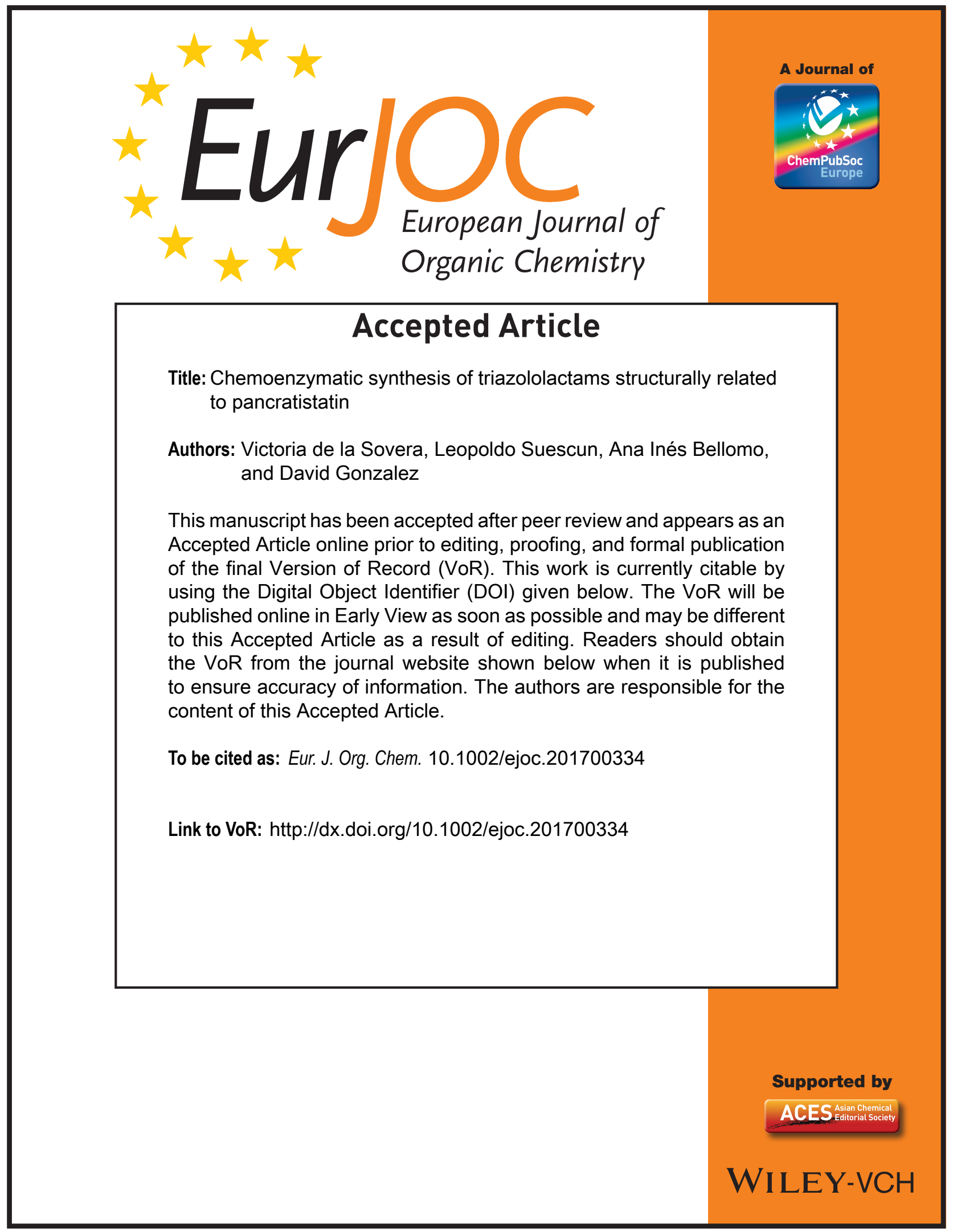




\title{
Chemoenzymatic synthesis of triazololactams structurally related to pancratistatin
}

Victoria de la Soveraa, Leopoldo Suescun ${ }^{b}$, Ana Bellomoc , and David Gonzalez ${ }^{a *}$

\author{
aDepartamento de Química Orgánica, Facultad de Química, Universidad de la República (UdelaR), \\ Montevideo, Uruguay \\ ${ }^{b}$ Laboratorio de Cristalografía, Estado Sólido y Materiales/Cátedra de Física/DETEMA, Facultad de \\ Química, Universidad de la República (UdelaR), Montevideo, Uruguay \\ ${ }^{c}$ Centro de Investigaciones en Bionanociencias (CIBION), Consejo Nacional de Investigaciones Científicas \\ y Técnicas (CONICET), Ciudad de Buenos Aires, Argentina
}

\begin{abstract}
Four tricyclic lactams that structurally resemble alkaloids with the pancratistatin skeleton were synthetized from bromobenzene by a chemoenzymatic strategy. The sequence involved enzymatic dihydroxylation, efficient stereodirected oxidation of double bonds, inter- or intramolecular Hüisgen cycloaddition and a solvent free cyclization. The complex structures were obtained in high chemical and optical purity and can be good candidates for biological testing.
\end{abstract}

\section{Introduction}

Alkaloids isolated from plants of the Amaryllidaceae family exhibit a wide structural diversity. ${ }^{1}$ Structures are complex involving polycyclic systems, aromatic and aliphatic rings and often several contiguous chiral centers. Traditional medicine alludes to Amaryllidaceae plant extracts to treat several diseases. Notably, extracts of daffodil, Narcissus poeticus L. were described by Hippocrates for the treatment of uterine tumors. ${ }^{2}$ Pure alkaloids isolated from the family are known anti-infective agents (antibacterial, antiparasitic and antiviral) and exhibit other biological properties. ${ }^{3}$

\footnotetext{
* Corresponding author. Tel.: (598) 2929-0106; fax: (598) 2924-1906; e-mail: davidg@fq.edu.uy
} 
Pancratistatin selectively induces apoptosis in cancer cells, but, the low availability of the natural alkaloid has obstructed its clinical studies and delayed progress. Recently, a recent report has summarized the advances in pancratistatin and pancratistatin unnatural analogues and concomitantly shed light on the mechanism of action of these molecules. ${ }^{4}$ This relevant report stated that pancratistatin acts on mitochondria to promote apoptosis and therefore disclosed the possibility of a new chemotherapy approach. Comparable results were also disclosed by Griffin et al. showing that natural pancratistatin induced apoptosis in cultivated colon cancer cells and reduced colon cancer in vivo. Some of the results suggested that the target of pancratistatin was mitochondria in cancer cells without affecting non-tumoral cell lines. ${ }^{5}$

Among the group, isocarbostyril alkaloids (Figure 1) are characterized for their isoquinolinone parent structure and the presence of an amidic nitrogen as part of a lactam ring. In a notable series of papers the Hudlicky group has developed not only efficient synthesis for several alkaloids of the pancratistatin family, but also discovered unnatural analogues of unsurpassed potency and bioavailability. 4,6

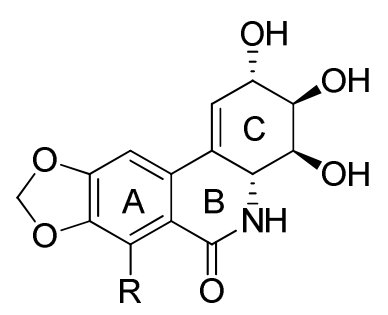

$$
\mathrm{R}=\mathrm{OH} \text {, narciclasine }
$$$$
\mathrm{R}=\mathrm{H} \text {, lycoricidine }
$$

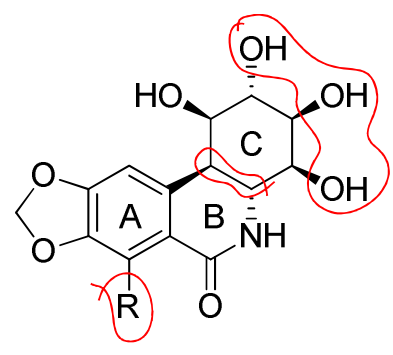

$\mathrm{R}=\mathrm{OH}$, pancratistatin

$\mathrm{R}=\mathrm{H}$, 7-deoxypancratistatin

Figure 1. The four alkaloids of the pancratistatin group

In recent years, the demand for methodologies and reactions that rapidly build structural complexity has grown exponentially, meeting three main requirements: efficiency, versatility and selectivity. Reactions with these main characteristics fall within the modern concept of "Click Chemistry" defined by Sharpless in $2001 . .^{7}$ This group of reactions, or synthetic methodologies, allow the medicinal chemists to quickly generate compound libraries to test and keep 
up with the vast amount of information provided by modern biological screening techniques, thus accelerating the process of drug discovery.

Hüisgen cycloaddition reemerged in its $\mathrm{Cu}(\mathrm{I})$ catalyzed version as the archetypic Click Chemistry reaction. ${ }^{8}$ However, for this project we found that $\mathrm{Cu}(\mathrm{I})$ catalysis was not required since high reactivity was achieved by using a doubly activated symmetric alkyne and an entropically favored intramolecular $[2+3]$ reaction.

In this sense, we prepared two pancratistatin analogues utilizing uncatalyzed versions of the Hüisgen reaction. The molecules resemble the natural alkaloid, as they mimic the cyclitol residue, yet the phenyl ring is substituted by a heteroaromatic triazole.

\section{Results and discussion}

Cyclitol ring $\mathrm{C}$ has been previously prepared by Hudlicky et al. in a remarkable sequence of research papers involving enzymatic dihydroxylation of aromatic compounds for the initial introduction of asymmetry. ${ }^{6 a}$, 6 h, 9 We have previously used this same strategy in the synthesis of several cyclitols ${ }^{10}$ and in our own first approach to pancratistatin analogs. ${ }^{10 d}$ Initially, the starting material was prepared by oxidation of bromobenzene with a mutant strain of $P$. putida discovered by Gibson et al. in the late 60s. ${ }^{11}$ Later, the development of recombinant strains that overexpress toluene dioxygenase (TDO) allowed the involved chemists to have available a supply of multigram quantities of the homochiral cyclohexadiene diol 2 to be used in a wide variety of synthetic ventures. ${ }^{10 \mathrm{j}, 12}$ Currently, the highest reported yield of 2 is around $40 \mathrm{G}$ per liter of culture medium. ${ }^{13}$ This result, obtained in our Department, can provide enough mass of optically pure precursor to support the work of several synthetic groups including ours. This diol 2 was protected as the corresponding acetonide and the later was transformed with excellent regio- and stereoselectivity using $N$-iodosuccinimide (NIS) into iodohydrin 4 as the major stereoisomer. ${ }^{12 e}$ Compound 4 was subjected to basic treatment to obtain an epoxide which was dehalogenated under classic radical conditions utilizing $\mathrm{HBu}_{3} \mathrm{Sn}$ as hydrogen donor and azobisisobutyronitrile (AIBN) as initiator ${ }^{14}$ in order to access epoxide 
6 (Scheme 1). Under these experimental conditions two new byproducts (6a and 6b) were observed, therefore decreasing the reaction yield. These byproducts, inseparable alongside compound 6, were identified by NMR and MS. Fortunately; this problem was successfully solved recycling $\mathbf{6 b}$ into starting material and $\mathbf{6 a}$ into the desired product (Scheme 2). Epoxide 6 was transformed into aziridine 9 as reported by Yadav et al. ${ }^{15}$ by nucloephilic ring opening with sodium azide, mesylation of the free alcohol and exposing this compound to Staudinguer reduction conditions. ${ }^{16}$ Finally, aziridine 9 was opened with sodium azide to provide key compound $\mathbf{1 0}$ in 15\% overall yield from diol 2.

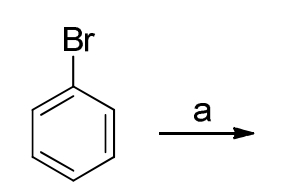

1

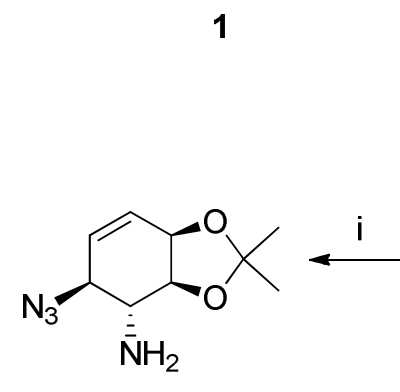

10

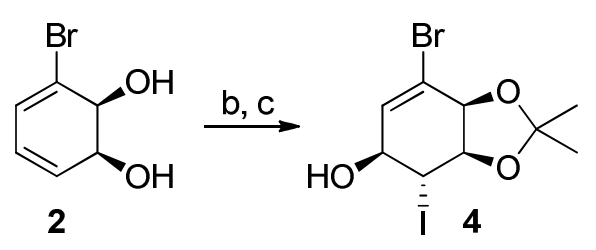

$\checkmark d, e$

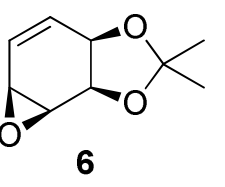

9
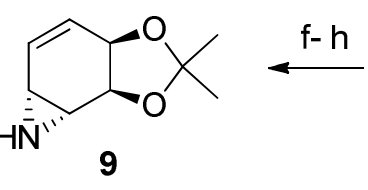

6

Scheme 1. Strategy towards the key 1,2-aminoazidocyclitol intermediate 10. a) toluene dioxigenase in E. coli JM109 (pDTG601), $40 \mathrm{~g} / \mathrm{L}$; b) DMP, acetone, $p$ $\mathrm{TsOH}$, r.t., $30 \mathrm{~min}, 90 \%$; c) NIS, DME: $\mathrm{H}_{2} \mathrm{O}$ (3:1), $0^{\circ} \mathrm{C}, 17$ h, $75 \%$; d) $\mathrm{NaOH}$, DME: $\mathrm{H}_{2} \mathrm{O}$ (3:1), 0 ๆ ${ }^{\circ}, 40$ min., 95\%; e) $\mathrm{HBu}_{3} \mathrm{Sn}$, AIBN, THF, reflux, 4 h, 61\%; f) $\mathrm{NaN}_{3}, \mathrm{NH}_{4} \mathrm{Cl}$, THF:EtOH: $\mathrm{H}_{2} \mathrm{O}$ (3:3:1) reflux, $\left.40 \mathrm{~min}, 77 \% ; \mathrm{g}\right) \mathrm{MsCl}, \mathrm{Et}_{3} \mathrm{~N}$, $\mathrm{CH}_{2} \mathrm{Cl}_{2}$, r.t., 1 h, 95\%; h) TPP, DIPEA, THF: $\mathrm{H}_{2} \mathrm{O}$ (4:1), reflux, 4h, 60\%; i) $\mathrm{NaN}_{3}$, $\mathrm{NH}_{4} \mathrm{Cl}$, THF:EtOH: $\mathrm{H}_{2} \mathrm{O}$ (3:3:1), reflux, 40 min., 85\%. 


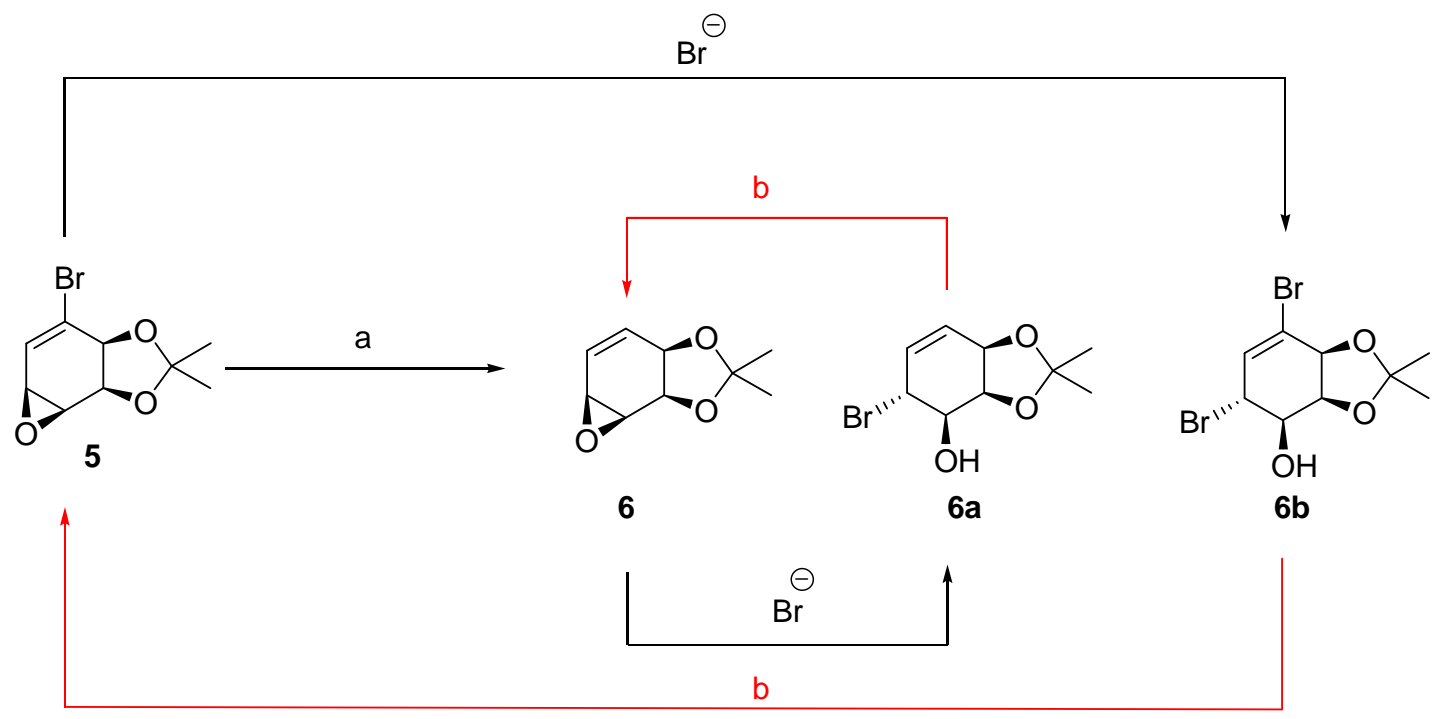

Scheme 2. Recycling cycle of the byproducts detected in the dehalogenation process. a) $\mathrm{HBu}_{3} \mathrm{Sn}$, AIBN, THF, reflux, $4 \mathrm{~h}, 61 \%$; b) $\mathrm{DBU}, \mathrm{CH}_{2} \mathrm{Cl}_{2}$, R.T., quantitative.

With compound $\mathbf{1 0}$ in hand we studied several amidation conditions and conclude that classical coupling conditions with DCC/DMAP in dry $\mathrm{CH}_{2} \mathrm{Cl}_{2}$ as solvent were the best providing 11 in 50\% yield. Amide 11 underwent intramolecular Hüisgen cycloaddition when heated in toluene, to render compound 14a (Route 1, Scheme 3). Another route (Route 2) was explored starting from 10 in which the amine group was also protected, in this case with a labile di-tert-butyl dicarbonate group, to allow an easier removal later in the synthesis. Protection yielded compound 12 that reacted with a symmetric alkyne to give the intermolecular Hüisgen cycloaddition product, triazole $\mathbf{1 3}$ in high yield (Route 2, Scheme 3). Interestingly, the catalyzed version of the Hüisgen reaction was also used on chiral derivatives of cyclohexadiene diols by Lewis et al. ${ }^{17}$ to render a chiral triazole carboxylic acid methyl ester from the corresponding alkyne. 


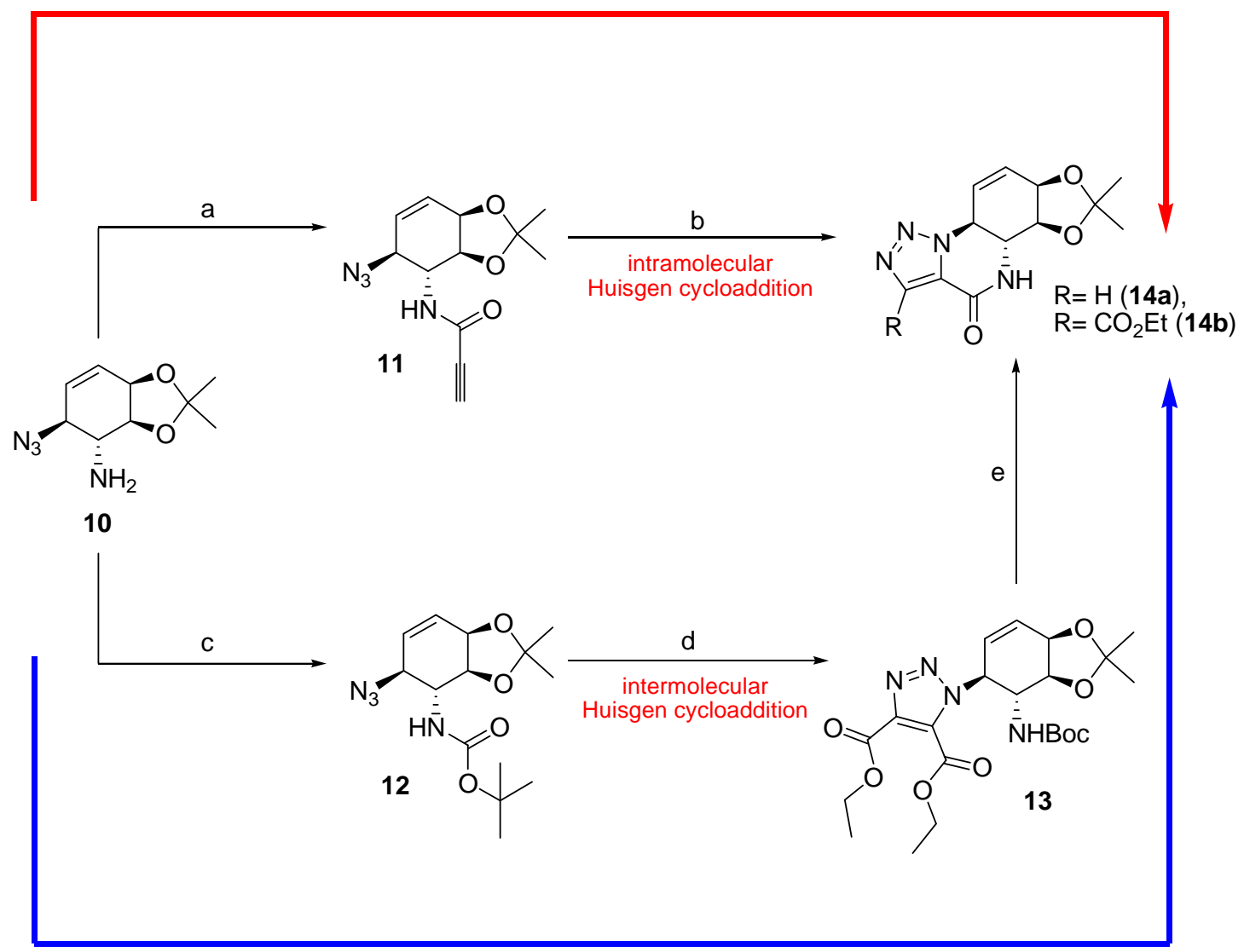

ROUTE 2

Scheme 3. Complementary approaches to tricyclic lactams. a) Propiolic acid, DCC, DMAP, $\mathrm{CH}_{2} \mathrm{Cl}_{2}, \mathrm{O}^{\circ} \mathrm{C}, 50 \mathrm{~min}, 50 \%$; b) toluene, reflux, $30 \mathrm{~min}$, $60 \%$; c) $\mathrm{Boc}_{2} \mathrm{O}, \mathrm{NaOH}, \mathrm{H}_{2} \mathrm{O} / \mathrm{t}-\mathrm{BuOH},(2 / 1), 0^{\circ} \mathrm{C}, 24$ h, 89\%; d) Diethylacetylendicarboxylate (DADC), toluene, reflux, 2 h, 90\%; e) $\mathrm{SiO}_{2}$, $110^{\circ} \mathrm{C}, 6 \mathrm{~h}, 71 \%$.

Following a procedure reported by Hudlicky et al. ${ }^{18}$ for the synthesis of other pancratistatin analogues we adsorbed triazole 13 in silica gel and heated the solid mixture to $110^{\circ} \mathrm{C}$. Compound 13 cyclized to provide lactam 14b in more than $70 \%$ yield. In this reaction, we detected, as a minor byproduct, the interesting derivative 15, which was identified by NMR as an isomer of compound 14b (Scheme 4). This compound probably resulted from the thermodynamically favored migration of the olefin to a conjugated position. 


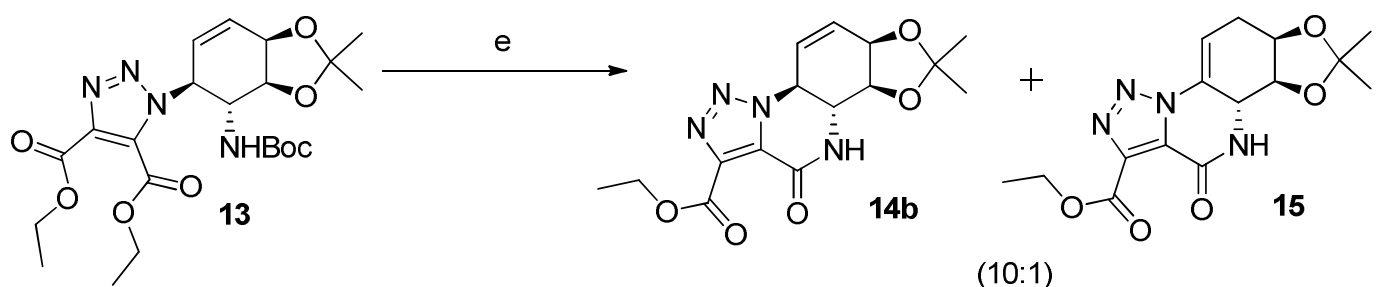

Scheme 4. Byproduct observed during cyclization of diester 13.

The next goal was to functionalize cyclitol ring C. For this purpose, we dihydroxylated the olefin present in compounds $14 \mathrm{a}$ and $14 \mathrm{~b}$. Our previous experience in the dihydroxylation of similar systems ${ }^{10 i}, 19$ including lactone analogous of pancratistatin indicated that classical osmium tetroxide oxidation will not react with our substrates. Therefore, we tried the stronger and greener oxidation system $\mathrm{RuCl}_{3} / \mathrm{NalO}_{4}$. We used a precisely defined mixture of solvents, $\mathrm{CH}_{3} \mathrm{CN} / \mathrm{AcOEt} / \mathrm{H}_{2} \mathrm{O}(3 / 3 / 1)$, in order to avoid oxidative cleavage of the double bond. ${ }^{19 a}$ Both precursors delivered a mixture of diastereomers with the anti product as the major isomer (Scheme 5). This result was expected due to the blocking effect of the $\beta$-face of the isopropylidene group which directed the reaction.

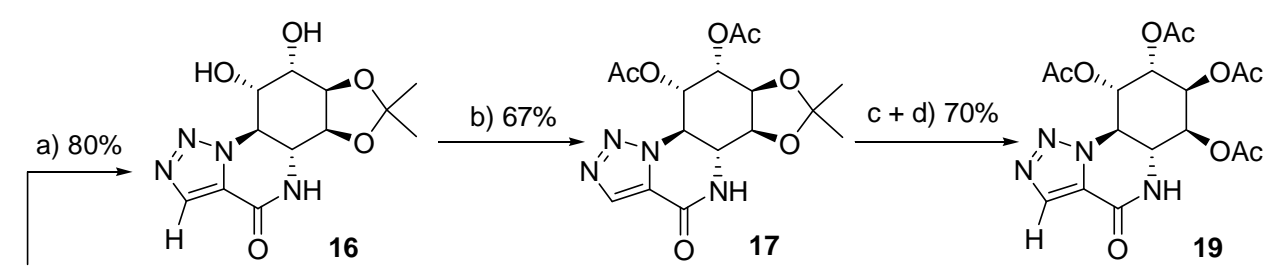<smiles>[R]c1nnn2c1C(=O)N[C@H]1[C@H](C=[13CH])OC(C)(C)O[C@@H]12</smiles>

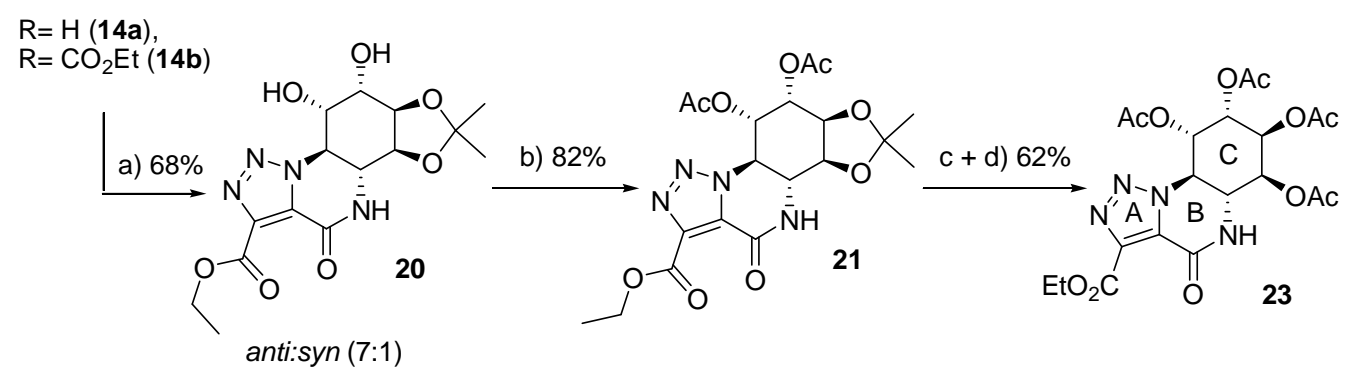


Scheme 5. Dihydroxylation and preparation of the alkaloid analogues. a) $\mathrm{RuCl}_{3}$, $\mathrm{NaIO}_{4}, \mathrm{CH}_{3} \mathrm{CN} / \mathrm{AcOEt} / \mathrm{H}_{2} \mathrm{O}$ (3/3/1), $0^{\circ} \mathrm{C}, 10 \mathrm{~min}$; b) $\mathrm{Ac} 2 \mathrm{O}, \mathrm{Et}_{3} \mathrm{~N}, \mathrm{DMAP}, \mathrm{CH}_{2} \mathrm{Cl}_{2}$, $0 \stackrel{\circ}{ } \mathrm{C}, 30 \mathrm{~min}, 67 \%$; c) DOWEX acidic resin, $\mathrm{H}_{2} \mathrm{O}, \mathrm{T}=90^{\circ} \mathrm{C}, 1 \mathrm{~h}$; d) $\mathrm{Ac}_{2} \mathrm{O}, \mathrm{Et}_{3} \mathrm{~N}$, DMAP, $\mathrm{CH}_{2} \mathrm{Cl}_{2}, 0^{\circ} \mathrm{C}, 30 \mathrm{~min}, 70 \%$.

Structure-activity studies performed on the natural product showed that in order to maintain biological activity, the hydroxyl group in $\mathrm{C} 2$ position must be anti to the diol function in $\mathrm{C} 3-\mathrm{C} 4.6 \mathrm{~g}, 20$ For this reason we focused our interest in the obtained anti products, 16 and $\mathbf{2 0}$ which were completely characterized as the corresponding diacetates 17 and 21. Stereochemical assignment of 16 was confirmed by X-ray diffraction analysis (Figure 2).

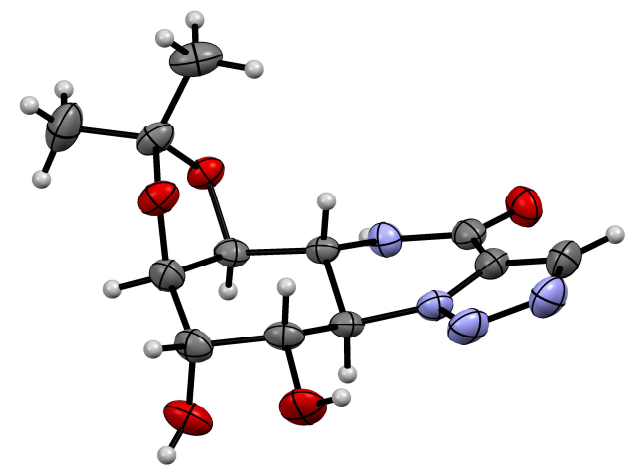

Figure 2. X-ray diffraction analysis of compound 16.

The endgame towards our final products 19 and 23, involved protecting the alcohols at positions $\mathrm{C} 1$ and $\mathrm{C} 2$ first, and exchanging the isopropylidene group at positions C3 and C4 for acetate protecting groups. In order to synthesize compounds with a higher degree of similarity to the natural product we synthesize tetraols 24 and 25 starting from compounds 16 and 20, deprotecting alcohols at positions C3 and C4 with acidic DOWEX resin using deuterated water as solvent to monitor consumption of the starting material analyzing directly from the reaction mixture by NMR (Scheme 6). In the case of compound 20 we had an ester group prone to undergo hydrolysis in these conditions. This required larger amounts of resin and longer reaction times. 
Summarizing, we managed to synthesize two analogues of these alkaloids, compound 24, analogue to 7-deoxypancratistatin, and compound 25 analogue to pancratistatin, due to the carboxylic acid triazole substituent. These compounds were synthesized from a common precursor, the aminoazide 10, with a global yield of $14 \%$ for compound 24 in four steps and $27 \%$ for compound $\mathbf{2 5}$ in five steps. Stereochemical assignment of $\mathbf{2 4}$ was confirmed by X-ray diffraction analysis (Figure 3 ).
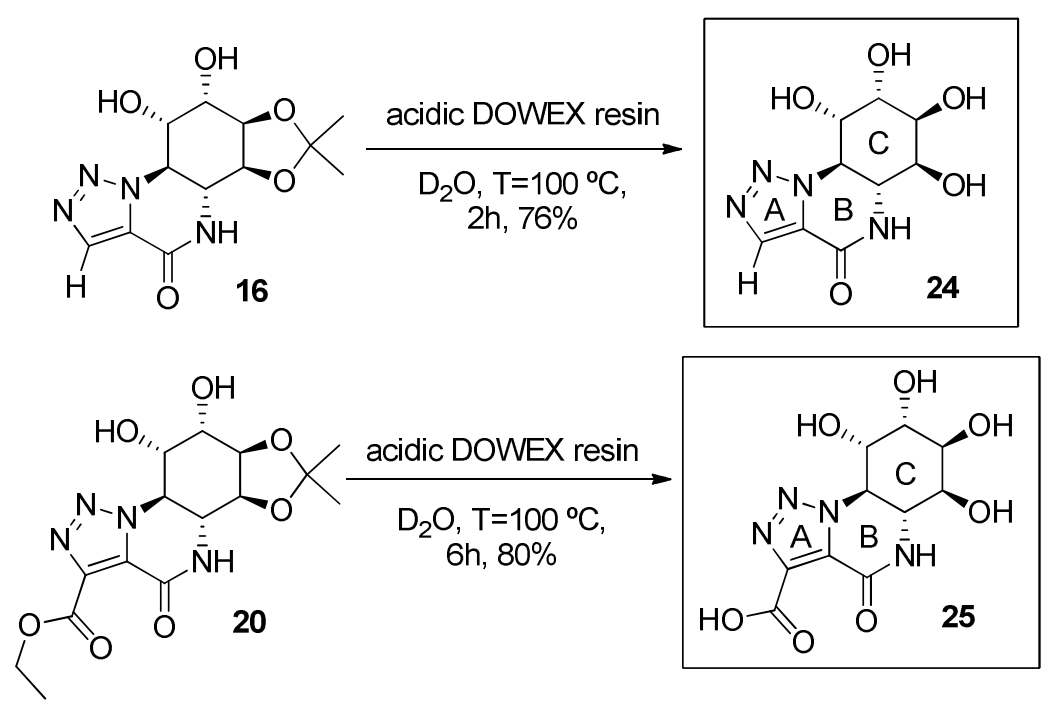

Scheme 6. Synthesis of tetraols 24 and 25 alkaloid analogues of 7deoxypancratistatin_and pancratistatin respectively.

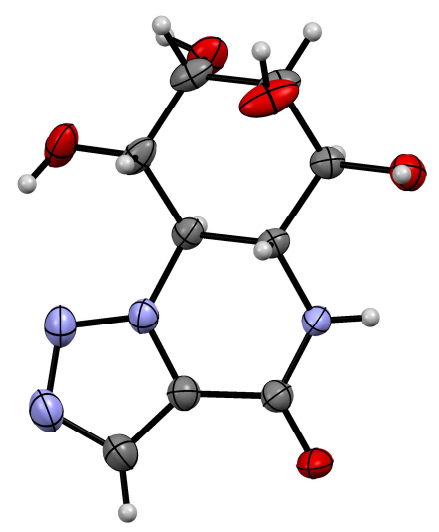

Figure 3. X-ray diffraction analysis of compound 24. 


\section{Acknowledgements}

We acknowledge ANII and CSIC-UdelaR for funding this project, VdIS acknowledges ANII and CAP-UdelaR for a graduate scholarship. We acknowledge Mario Macias for his assistance with crystallographic data collection. NMR spectra were recorded by Horacio Pezaroglo and Verónica Martínez, HRMS were recorded by David Menchaca and Dr. Alejandra Rodriguez.

CCDC 1535960 and 1535961 contains the supplementary crystallographic data for compounds 16 and 24 respectively. The data can be obtained free of charge from The Cambridge Crystallographic Data Centre via www.ccdc.cam.ac.uk/structures.

Keywords: Alkaloids, Asymmetric synthesis, Chemoenzymatic, Click chemistry, Cycloaddition

\section{Bibliography}

[1] M. He, C. Qu, O. Gao, X. Hu, X. Hong, RSC Advances 2015, 5, 16562.

[2] A. Kornienko, A. Evidente, Chem. Rev. 2008, 108, 1982.

[3] a) D. Lamoral-Theys, A. Andolfi, G. Van Goietsenoven, A. Cimmino, B. Le Calvé, N. Wauthoz, V. Mégalizzi, T. Gras, C. Bruyère, J. Dubois, V. Mathieu, A. Kornienko, R. Kiss, A. Evidente, J. Med. Chem. 2009, 52, 6244; b) G. Van Goietsenoven, A. Andolfi, B. Lallemand, A. Cimmino, D. Lamoral-Theys, T. Gras, A. Abou-Donia, J. Dubois, F. Lefranc, V. Mathieu, A. Kornienko, R. Kiss, A. Evidente, J. Nat. Prod. 2010, 73, 1223; c) P. Cao, D.-S. Pan, S. Han, C.-Y. Yu, Q.-J. Zhao, Y. Song, Y. Liang, Arch. Pharmacal Res. 2013, 36, 927.

[4] D. Ma, C. Pignanelli, D. Tarade, T. Gilbert, M. Noel, F. Mansour, S. Adams, A. Dowhayko, K. Stokes, S. Vshyvenko, T. Hudlicky, J. McNulty, S. Pandey, Sci. Rep. 2017, 7, 42957.

[5] C. Griffin, A. Karnik, J. McNulty, S. Pandey, Mol. Cancer Ther. 2011, 10, 57.

[6] a) M. Ghavre, J. Froese, M. Pour, T. Hudlicky, Angew. Chem. Int. Ed. 2016, 55, 5642 ; b) S. Vshyvenko, Z. W'Giorgis, A. Weber, N. Neverova, B. Hedberg, T. Hudlicky, Adv. Synth. and Catal. 2015, 357, 83; c) S. Vshyvenko, M. R. Reisenauer, S. Rogelj, T. Hudlicky, Bioorg. Med. Chem. Lett. 2014, 24, 4236; d) 
D. Ma, P. Tremblay, K. Mahngar, P. Akbari-Asl, J. Collins, T. Hudlicky, J. McNulty, S. Pandey, Investigational New Drugs 2012, 30, 1012; e) D. Ma, J. Collins, T. Hudlicky, S. Pandey, JoVE 2012; f) S. Vshyvenko, J. Scattolon, T. Hudlicky, A. E. Romero, A. Kornienko, Bioorg. Med. Chem. Lett. 2011, 21, 4750; g) U. Rinner, H. L. Hillebrenner, D. R. Adams, T. Hudlicky, G. R. Pettit, Bioorg. Med. Chem. Lett. 2004, 14, 2911; h) T. Hudlicky, U. Rinner, D. Gonzalez, H. Akgun, S. Schilling, P. Siengalewicz, T. A. Martinot, G. R. Pettit, J. Org. Chem. 2002, 67, 8726.

[7] J. Bastida, S. Berkov, L. Torras, N. B. Pigni, J. P. de Andrade, V. Martínez, C. Codina, F. Viladomat, in Transworld Research Network, Vol. 1 (Ed. : D. MuÇoz-Torrero), 2011, p. 65.

[8] a) H. C. Kolb, M. G. Finn, K. B. Sharpless, Angew. Chem., Int. Ed. Engl. 2001, 40, 2004; b) P. Wu, A. K. Feldman, A. K. Nugent, C. J. Hawker, A. Scheel, B. Voit, J. Pyun, J. M. J. Fréchet, K. B. Sharpless, V. V. Fokin, Angew. Chem. Int. Ed. 2004, 43, 3863.

[9] a) T. Hudlicky, X. Tian, K. Königsberger, R. Maurya, J. Rouden, B. Fan, J. Am. Chem. Soc. 1996, 118, 10752; b) X. Tian, T. Hudlicky, K. Königsberger, J. Am. Chem. Soc. 1995, 117, 3643; c) S. S. Vshyvenko, J.; Hudlicky, T.; Romero, A. E.; Kornienko, A.; Ma, D.; Tuffley, I.; Pandey, S., Can. J. Chem. 2012, 90, 1.

[10] a) N. Thevenet, V. de la Sovera, M. A. Vila, N. Veiga, D. Gonzalez, G. Seoane, I. Carrera, Org. Lett. 2015, 17, 684; b) V. de la Sovera, P. Garay, N. Thevenet, M. A. Macías, D. González, G. Seoane, I. Carrera, Tetrahedron Lett. 2016, 57, 2484; c) V. de la Sovera, A. Bellomo, J. M. Pena, D. Gonzalez, H. A. Stefani, Mol. Divers. 2011, 163; d) V. de la Sovera, A. Bellomo, D. Gonzalez, Tetrahedron Lett. 2011, 52, 430; e) G. Carrau, C. C. Drewes, A. L. B. Shimada, A. Bertucci, S. H. P. Farsky, H. A. Stefani, D. Gonzalez, Bioorg. Med. Chem. 2013, 21, 4225; f) A. B. Bellomo, A.; de la Sovera, V.; Carrau, G.; Raimondi, M.; Zacchino, S.; Stefani, H. A.; Gonzalez, D., Lett Drug Des Discov 2014, 11, 67; g) A. Bellomo, A. Bertucci, H. A. Stefani, A. Vázquez, D. Gonzalez, Tetrahedron: Asymm. 2009, 20, 2673; h) A. Bellomo, J. B. Bonilla, J. LópezPrados, M. Martín-Lomas, D. Gonzalez, Tetrahedron: Asymm. 2009, 20, 2061; i) A. Bellomo, S. Camarano, C. Rossini, D. Gonzalez, Carbohydr. Res. 2009, 344, 44; j) A. Bellomo, D. Gonzalez, H. A. Stefani, J. Organomet. Chem. 2008, $693,1136$. 
[11] a) D. T. Gibson, J. R. Koch, C. L. Schuld, R. E. Kallio, Biochemistry 1968, 7, 3795; b) D. T. Gibson, M. Hensley, H. Yoshioka, T. J. Mabry, Biochemistry 1970, 9, 1626.

[12] a) M. Brovetto, V. Schapiro, G. Cavalli, P. Padilla, A. Sierra, G. Seoane, L. Suescun, R. Mariezcurrena, New J. Chem. 1999, 23, 549; b) M. Labora, V. L. Heguaburu, E. M. Pandolfi, V. Schapiro, Tetrahedron: Asymm. 2008, 19, 893; c) M. Brovetto, G. Seoane, J. Org. Chem. 2008, 73, 5776; d) I. Carrera, M. C. Brovetto, G. A. Seoane, Tetrahedron Lett. 2006, 47, 7849; e) I. Carrera, M. C. Brovetto, G. Seoane, Tetrahedron 2007, 63, 4095.

[13] M. A. Vila, M. Brovetto, D. Gamenara, P. Bracco, G. Zinola, S. Rodríguez, G. Seoane, I. Carrera, J. Mol. Catal. B: Enzym. 2013, 96, 14.

[14] a) H. A. J. Carless, Tetrahedron Lett. 1992, 33, 6379; b) T. Hudlicky, H. Luna, H. F. Olivo, C. Andersen, T. Nugent, J. D. Price, J. Chem. Soc. Perk. T. 1 1991, 2907.

[15] J. S. Yadav, G. Satheesh, C. V. S. R. Murthy, Org. Lett. 2010, 12, 2544.

[16] H. M. Staudinger, J., Helv. Chim. Acta 1919, 2, 635.

[17] J. a. Griffen, A. M. Le Coz, G. Kociok-Köhn, M. A. Khan, A. J. W. Stewart, S. E. Lewis, Org. Biomol. Chem. 2011, 9, 3920.

[18] T. Hudlicky, U. Rinner, K. J. Finn, I. Ghiviriga, J. Org. Chem. 2005, 70, 3490.

[19] a) M. Desjardins, L. E. Brammer Jr, T. Hudlicky, Carbohyd. Res. 1997, 304, 39;

b) B. Plietker, M. Niggemann, Org. Lett. 2003, 5, 3353.

[20] a) F. Chrétien, S. I. Ahmed, A. Masion, Y. Chapleur, Tetrahedron 1993, 49, 15; b) J. McNulty, J. Mao, R. Gibe, R. Mo, S. Wolf, G. R. Pettit, D. L. Herald, M. R. Boyd, Bioorg. Med. Chem. Lett. 2001, 11, 169. 